\title{
The Retail Gasoline \\ Price-Fixing Cartel \\ in Québec
}

MARCEL BOYER

\section{CIRANO}

Allier savoir et décision 


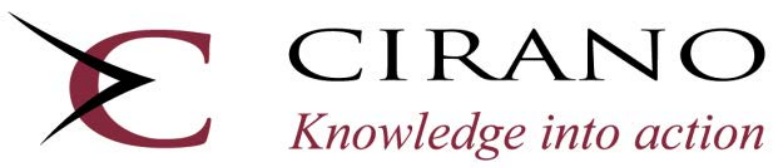

Center for Interuniversity Research and Analysis on Organizations

The purpose of the Working Papers is to disseminate the results of research conducted by CIRANO research members in order to solicit exchanges and comments. These reports are written in the style of scientific publications. The ideas and opinions expressed in these documents are solely those of the authors.

Les cahiers de la série scientifique visent à rendre accessibles les résultats des recherches effectuées par des chercheurs membres du CIRANO afin de susciter échanges et commentaires. Ces cahiers sont rédigés dans le style des publications scientifiques et n'engagent que leurs auteurs.

CIRANO is a private non-profit organization incorporated under the Quebec Companies Act. Its infrastructure and research activities are funded through fees paid by member organizations, an infrastructure grant from the government of Quebec, and grants and research mandates obtained by its research teams.

Le CIRANO est un organisme sans but lucratif constitué en vertu de la Loi des compagnies du Québec. Le financement de son infrastructure et de ses activités de recherche provient des cotisations de ses organisations-membres, d'une subvention d'infrastructure du gouvernement du Québec, de même que des subventions et mandats obtenus par ses équipes de recherche.

\section{CIRANO Partners - Les partenaires du CIRANO}

Corporate Partners - Partenaires corporatifs

Autorité des marchés financiers

Bank of Canada

Bell Canada

BMO Financial Group

Business Development Bank of Canada

Caisse de dépôt et placement du Québec

Desjardins Group

Énergir

Hydro-Québec

Innovation, Science and Economic Development Canada

Intact Financial Corporation

Manulife Canada

Ministère de l'Économie, de la Science et de l'Innovation

Ministère des finances du Québec

National Bank of Canada

Power Corporation of Canada

PSP Investments

Rio Tinto

Ville de Montréal

Academic Partners - Partenaires universitaires

Concordia University

École de technologie supérieure

École nationale d'administration publique

HEC Montréal

McGill University

National Institute for Scientific Research

Polytechnique Montréal

Université de Montréal

Université de Sherbrooke

Université du Québec

Université du Québec à Montréal

Université Laval

CIRANO collaborates with many centers and university research chairs; list available on its website. Le CIRANO collabore avec de nombreux centres et chaires de recherche universitaires dont on peut consulter la liste sur son site web.

(C) February 2021. Marcel Boyer. All rights reserved. Tous droits réservés. Short sections may be quoted without explicit permission, if full credit, including (C) notice, is given to the source. Reproduction partielle permise avec citation du document source, incluant la notice (C).

The observations and viewpoints expressed in this publication are the sole responsibility of the authors; they do not necessarily represent the positions of CIRANO or its partners. Les idées et les opinions émises dans cette publication sont sous l'unique responsabilité des auteurs et ne représentent pas nécessairement les positions du CIRANO ou de ses partenaires. 


\title{
THE RETAIL GASOLINE PRICE-FIXING CARTEL IN QUEBEC
}

\author{
MARCEL BOYER
}

Emeritus Professor of Economics, Université de Montréal; Associate Member, Toulouse School of Economics; Fellow of CIRANO and of the C.D. Howe Institute; Academic Affiliate, Analysis Group

\section{Revised October 2021}

\begin{abstract}
Prosecution of the retail gasoline price-fixing cartel in Quebec was the culmination of the largest and one of the most successful criminal investigations in the history of the Competition Bureau of Canada. In June 2008 the first charges were brought against 38 individuals and 14 companies under Section 45 of the pre-2010 Competition Act. The last trial occurred in the Fall of 2019. Pre-2010 Competition Act means that the public prosecutor had to show that the cartel not only existed but also had the effect of "unduly lessening competition." Pre-2010, an unsuccessful cartel was not a crime. As an expert witness and author of the crucial economic report in the case, I here review the significant empirical challenges faced and how they were dealt with to credibly conclude that the cartel did successfully increase prices in the markets under investigation. Price data, namely the dynamic standard deviation of prices across retailers, indicated that the cartel began in early 2001, while the charges only covered the period after early 2004. Based on a difference-indifferences approach, the best estimate of damages the city-based cartels imposed on customers ranges from $\$ 18.5 \mathrm{M}$ to $\$ 42.0 \mathrm{M}$ for the period $2001-2006$, and from $\$ 6.7 \mathrm{M}$ to $\$ 20.9 \mathrm{M}$ for the period 2004-2006. In addition to fines imposed on individuals and companies pleading or found guilty, numerous individuals received conditional prison sentences.
\end{abstract}

Keywords: retail gasoline markets, price-fixing cartel, difference-in-differences, undue lessening of competition.

J.E.L. Classification: L41, K14, C81

Acknowledgements: I am grateful to Lisa Pinheiro and Anne Catherine Faye of Analysis Group for their very valuable help, to the teams at the Competition Bureau and the Public Prosecution Service of Canada as well as the legal teams of defendants in the different trials for their comments and vigorous questioning. I remain solely responsible for the content of this article. 


\section{Introduction}

Canada's Competition Bureau investigated allegations of collusion and price-fixing by owners of gas stations in four cities in Quebec: Sherbrooke, Victoriaville, Thetford Mines, and Magog. The period covered was from early 2004 to mid-2006. The inquiry was triggered by complaints filed with the Bureau by gas station operators who were harassed by other operators for their unwillingness to participate in a price-fixing scheme.

Prior to the 2010 amendments to the Competition Act, it was not unlawful per se in Canada to conspire to fix prices. Section 45 of the Act required that the lessening of competition resulting from the collusion be successful, undue or substantial. Even when participants in the conspiracy collectively had a significant share of the market in which they operated, it did not automatically follow that the net harm to competition would make the conspiracy unlawful, since the rules or guidelines for substantiating an undue lessening of competition were far from clear. ${ }^{1}$ The new conspiracy provisions in section 45 of the Act limit the criminal offence to so-called "naked cartels," that is, cartels designed to fix prices, allocate markets, or restrict output. They render it unnecessary to demonstrate an anti-competitive effect or undue lessening of competition in order to secure a criminal conviction. ${ }^{2}$

Since the Quebec retail gasoline cartel case was a pre-2010 case, the public prosecutor (Public Prosecution Service of Canada - PPSC) had to show that the cartel not only existed but did have the effect of unduly lessening competition. The existence of the conspiracy was established on the basis of the wiretapping of operators' conversations over a two and a half year period, from early 2004 to June 2006. Hence the proof of the existence of a conspiracy was quite direct. The remaining challenge was to show that the cartel did bite - that is, did result in an undue lessening of competition and a significant increase in prices. That is where and when the economist becomes the law enforcement flag bearer.

\footnotetext{
${ }^{1}$ Boyer, Ross, and Winter (2017). See also https://marcomm.mccarthy.ca/pubs/cach3.htm and https://lawslois.justice.gc.ca/eng/acts/C-34/section-45-20021231.html

${ }^{2}$ Fanaki (2010). See also https://www.competitionbureau.gc.ca/eic/site/cb-bc.nsf/eng/02585.html
} 
On the basis of wiretaps and the results of the economic report (Boyer 2007/2008 ${ }^{3}$ ) showing that the cartel was indeed successful in unduly lessening competition between station operators, the PPSC decided to lay charges of criminal price-fixing against participating service station operators and some higher-up managers. The first charges were filed in June 2008. Over all, some 38 individuals and 14 companies were charged under Section 45 of the Competition Act. ${ }^{4}$ This case is the largest and one of the most successful criminal investigation in the history of the Competition Bureau of Canada. ${ }^{5}$ The last trial occurred before a jury in the Fall of 2019 in the Criminal and Penal Division of the Superior Court of Quebec.

\section{Challenges}

Conspiracies are, by their secret nature, very difficult to detect and prove. Identical prices may result from generally available information and intense competition. The retail gasoline cartel case we examine here is of interest because it poses significant and unique challenges:

(i) Given that gas prices are openly announced and that transactions are repeated and numerous, a local (city-wide) cartel cannot raise prices by a large amount. However, artificial price increases may be small (a few cents or less per unit) but statistically significant. Hence the impact may be limited on a small number of purchases, but may still amount to millions of dollars overall.

\footnotetext{
${ }^{3}$ The Report was completed in July 2007, one year after the confirmation by the Bureau that an investigation was under way, but officially signed in July 2008 and, from then on, used in court cases as well as in plea bargaining cases.

${ }^{4}$ For more detailed information on the "Quebec Gasoline Price-Fixing Cartel," see the Canadian Competition Bureau website at: http://www.competitionbureau.gc.ca/eic/site/cb-bc.nsf/eng/03079.html. The internal working of the cartels including extensive communications among members and the price adjustments that supported the collusion by controlling deviations was studied by Clark and Houde (2013, 2014). Erutku and Hildebrand (2010) derived an estimate of the price overcharge and the ensuing damage for one year (2005-2006) in the city of Sherbrooke. I discuss those results below.

${ }^{5}$ Melanie L. Aitken, Commissioner of Competition, CBA Fall Competition Law Conference, Gatineau (QC), September 30, 2010, said (https://www.competitionbureau.gc.ca/eic/site/cb-bc.nsf/eng/03205.html): "The Bureau is increasingly making use of wiretaps in its investigations - a tool that played an important part in the largest criminal investigation in the history of the Bureau, which concluded this summer with new criminal charges laid against individuals and companies accused of fixing the price of gasoline in Quebec." In the Competition Bureau submission to the OECD Competition Committee Roundtable on Cartels, Oct. 13 2013, one reads: "This investigation of retail gas prices in Quebec has been one of the Bureau's most successful cases to date." https://www.competitionbureau.gc.ca/eic/site/cb-bc.nsf/eng/03770.html
} 
(ii) Gasoline prices move up and down quickly, often more than once a day. Thus, comparing prices is a real challenge, especially since prices are recorded at most a few times per year at dates that differ between markets.

(iii) A retail gasoline cartel involving numerous local station operators will continuously be vulnerable to defection by one or more participants, which implies that the cartel must be re-established regularly, typically more than once per week.

(iv) Accurately assessing damages may be challenging because the cartel duration used by the antitrust authorities (Competition Bureau) may be different from the one suggested by economic data analysis.

(v) Comparing prices in cities where collusion was observed with "but-for" prices from comparable cities is a major challenge insofar as market conditions in the different cities are difficult to observe and assess.

(vi) Finally, estimating damages in a consistent way and determining their statistical significance is another difficult challenge as it requires blending different data sources.

To prosecute cartel members, firms and individuals, the Public Prosecution Service of Canada needed a definition of the relevant market structure and a measure of the market power of participants during the collusion, as well as proper data analysis on prices and volumes in the cartelized markets and in benchmark markets to evaluate whether the dynamic evolution of prices was indeed consistent with the existence of collusion and, if so, to obtain a measure of damages.

Gasoline is a good with a relatively uniform quality. Its market is generally determined by a radius around the most used roads, that is, along the main roads of a city or its neighborhoods. In general, drivers are responsive to gasoline prices that they observe during their ride. However, they will not travel long distances, costly in terms of time and gas, simply to find a better price. Therefore, the market is geographically limited to a relatively small radius around relevant locations or streets in a city for local trips or around roads used for intercity travel.

The extent of the damages to consumers depends on the value of the overcharge, i.e. the difference between the inflated price level created by the cartel and the price level that would emerge from normal competition between retailers. In order to isolate the impact of the cartel on prices, a difference-in-differences analysis was used to compare prices in cartelized cities to those in 
benchmark collusion-free cities covering the period of collusion and bracketing periods, before and after, in order to measure the part of the price increase that could be considered "abnormal" given the general market dynamics.

I show here how these challenges were met to determine whether the cartel did bite and, if so, to estimate the resulting damages for customers. As the author of the economic report, which was used by the PPSC in criminal court as well as in plea bargaining and out-of-court settlements, I testified in numerous criminal trials. It may be of interest to mention that I was vigorously crossexamined, as is expected in criminal cases, but the defendants and their lawyers brought forth no counter-expertise, no counter-reports, and no counter-experts.

Section 2 presents data sources used and their limitations and Section 3 discusses the market structure and the market power of participants in the different cartels (one per city). Section 4 compares price dynamics in a difference-in-differences analysis between cartelized and benchmark markets to determine whether their comparative dynamics are consistent with collusion in the first group and to identify the relevant collusive periods. Section 5 presents the collusion impact on prices and the damage assessment. Section 6 concludes.

\section{The data}

Data used for the detailed analyses were obtained from two main sources: Kent Marketing and the Quebec energy board (Régie de l'énergie du Québec).

Kent Marketing ${ }^{6}$ is a private Canadian company, based in Ontario, which compiles detailed quarterly or bimonthly data on the gasoline prices and volumes of sales for each gas station in many Canadian cities. We obtained price and volume data from Q1-1993 to Q2-2006 for gas stations in Sherbrooke, Victoriaville, and Thetford Mines, and from Q4-2005 to Q2-2006 for gas stations in Magog. In order to establish a baseline, several cities were chosen to serve as benchmarks. These included Montreal, split into Montreal-Centre and Montreal-South, which are suitable choices due to their sizes, given the reasonable assumption that the effects of collusion cannot significantly affect the general dynamics of their retail gasoline markets. The other city chosen to serve as a benchmark is Saint-Hyacinthe, whose size is similar and location closer to the cities where collusion was confirmed by wiretaps.

\footnotetext{
${ }^{6}$ More information about the company is available on their Web site at www.kentmarketing.on.ca.
} 
Since the survey by Kent Marketing for the Montreal region is conducted on a bimonthly basis, data obtained cover B2-1993 to B4-2006 for those two markets; for Saint-Hyacinthe, data cover Q1-1993 to Q2-2006. Quantities sold and dates on which the surveys were conducted vary from year to year and from one city to another. The absence of synchronization makes it difficult, or even impossible, to establish a direct price comparison between different cities.

The Régie de l'énergie du Québec publishes a newsletter on the prices of petroleum products in Quebec (Bulletin d'information sur les prix des produits pétroliers) which provides a weekly survey of prices posted in various regions of Quebec, as well as the legal minimum price as calculated by the Régie for each of these regions. ${ }^{7}$ The weekly data on average prices per city has been available since December 1997. The sample is based on 297 retailers among 4,000 retailers in 187 cities or boroughs and 17 regions. As for the minimum estimated legal price, it is calculated on a weekly basis, using the minimum price at the loading dock on the preceding Thursday, adjusted to each city's specific taxes and transportation costs. This measure is quite useful because it allows us to compare prices between different cities taking into account tax and transportation cost variations between regions over time.

Data supplied by the Régie de l'énergie do not provide any information on price variations between retailers in the same city. Furthermore, the average price sample usually includes one or two retailers per city. It is therefore possible that the average price listed by the Régie is not always equal to the actual average price charged in a specific city.

\section{Market structure and market power}

Gasoline is a standardized good, even if some consumers prefer one retailer over another for its location, its ancillary services, or its lower pump price. With regard to drivers' reactions to pump prices, many factors come into play. Demand elasticity ${ }^{8}$ for gasoline is usually low in the short term, varying between -0.04 and -0.40 , but higher in the long term, varying between -0.23 to 1.37. Gasoline demand elasticity refers to a uniform increase in pump prices across relevant buying

\footnotetext{
${ }^{7}$ See the Régie de l'énergie's website at http://www.regie-energie.qc.ca/energie/petrole_tarifs.php.

8 "MTBE Phase Out in California" Consultant Report. California Energy Commission. Publication 600-02-008CR. March 14, 2002 www.energy.ca.gov/reports/2002-03-14_600-02-008CR.PDF. These estimates are consistent with our estimate of short term demand elasticity of -0.2 which we obtained using input data. The detailed results of this estimation are available in Boyer (2008). Other studies confirm such estimates, for example, those by the Organisation for Economic Co-operation and Development (OECD) and by Dahl and Sterner, "Analyzing Gasoline Demand Elasticities: A Survey." Energy Economics. Vol 13(3):203-210. July 1991.
} 
locations. But it is the demand elasticity per retailer that provides information concerning a retailer's ability to move alone in increasing prices without losing market share. The retailer's own price elasticity is high $^{9}$ and so it is difficult for a retailer to be the only one to increase its price.

The only way for retailers to increase their prices above the market equilibrium price is to enter into an implicit or explicit price-fixing agreement, and apply price increases somewhat simultaneously across most if not all retailers. However, this would then provide each retailer with the incentive to deviate from the collusive agreement and to unilaterally decrease the price at the pump to profit from the high elasticity. This is one of the reasons why gas price-fixing cohesion in an implicit or explicit agreement is difficult to maintain, unless participating retailers agree to exert sustained and significant implementation and organizational efforts. Continued follow-up between retailers is therefore necessary to obtain and maintain a price increase as part of collusive activities in a market such as gasoline.

Another important factor that can affect the viability of a gasoline cartel is the ease with which new retailers can enter or exit the market if they become tempted to compete with the cartel to profit from the overcharge created by the cartel. Oil refiners and retailers (Imperial, Shell, PetroCanada, Ultramar, ...) and independent retailers (entrepreneurs, Couche-Tard, Olco, Canadian Tire, ...) are the two distinct groups in charge of marketing and selling gasoline in Canada. ${ }^{10}$ Based on the data retrieved by Kent Marketing in September 2005 in Sherbrooke, the three main commercial refiners had a $48.5 \%$ market share followed by the regional commercial refiners, Irving and Ultramar, with $35.2 \%$ and finally the independent retailers with $16.4 \%$.

The presence of commercial refiners with significant market share can be a major barrier to entry by new independent retailers. Indeed, substantial economies of scale characterize the gasoline retail industry. Furthermore, economies of scope, such as the possibility of selling affordable ancillary products, should not be overlooked. The substantial costs incurred in opening a new gas station and the cost of quickly acquiring a profitable market share are therefore significant barriers to entering the market. In recent years, some supermarkets (Wal-Mart, Costco, Loblaws, etc.) have become more visible competitors on the gasoline retail market. Newcomers have sold considerable

\footnotetext{
9 The elasticity per retailer can reach values of -18 , according to Wang (2008).

${ }^{10}$ In Canada, the three main merchant refiners are Imperial Oil with approximately 2,000 gas stations, Shell Canada with 1,681 stations and Petro-Canada with over 1,500 retail and wholesale outlets. Source: each merchant refiner's web site.
} 
volumes of gasoline, without necessarily generating profits comparable to those of other types of gas stations, because selling gasoline allows them to drive traffic to their stores and increase sales of their other products.

On a global scale, it therefore seems that the gasoline retail market is not very favorable to the rapid arrival of new players when the "high" price of gas offers cost effective investment opportunities. The trend over the past decades has rather been a rationalization of the number of gas stations, and we have noticed a relatively constant decline in their number in various cities, especially those of interest here. The short-term variation in the number of gas stations is minimal. We therefore have a market dynamic with the characteristics required to accommodate potentially viable and efficient cartels, insofar as they can count on large market shares and on the relative difficulty of entering the market. Another helpful factor would be if cartel participants were able to count on an efficient organization to coordinate decisions, to convince all those involved, and to quickly and accurately observe any deviant behaviour.

In the gasoline market, the relevant geographical distribution of sellers and buyers is practically the same, and so gas stations tend to be near groups of consumers and near the main roads used by buyers. Each of the relevant city markets is well defined by its service stations, other service stations being sufficiently far away and inaccessible to be disqualified as serious competitors.

In the present case, individual gas stations have no market power. However, the collective market power of the gas stations which are part of the price-fixing cartel is large in each of the four markets investigated. Indeed, the market share of the gas stations participating in the respective cartels, as shown by direct or indirect proof, reached 89\% (2005) and 87\% (2006) in Sherbrooke, 93\% (2005 and 2006) in Thetford Mines, 98\% (2005) and 99\% (2006) in Victoriaville, and 92\% (2006) in Magog.

\section{The dynamics of price volatility across retailers}

Communication between retailers results in a much quicker price adjustment than what we would see if retailers had to find an "equilibrium" by trial and error. Hence, we expect price differences observed at a given time between gas stations to be smaller and less variable over time in a cartelized market than under normal competition. I will show that indeed the standard deviation of prices across retailers in cities where a cartel was shown to exist (by wiretapping) fell significantly 
in early 2001 and remained low as compared to benchmark no-cartel cities. This is a significant cartel marker.

Harrington (2006) presents eight such markers, defined as "some property of firm behavior which is much more consistent with collusion than with competition." One of his markers is "Increased uniformity across firms in product price, quality, and the prices for ancillary services." Connor (2005) states that although there are suggestions that price dispersion changes when cartelization of a market occurs, there are few empirical analyses of this effect. He discusses four empirical studies of cartels where this was observed, of which the Abrantes-Metz, Froeb, and Taylor (2004) study of a bid-rigging cartel in frozen fish is the clearest case. The results presented in the next section show a statistically significant reduction in the average and variance of the standard deviation of prices across retailers in cartel cities (as identified by wiretaps), not only over time but also in comparison with benchmark no-cartel city markets.

In this context, I analyzed the price volatility dynamics between retailers over time (1993-2006) for Sherbrooke, Thetford Mines, and Victoriaville, and also for Montreal-Centre, Montreal-South, and Saint-Hyacinthe, using retailer-specific data as provided by Kent Marketing. The standard deviations of prices between retailers in cents per liter (CPL) over 1993-2006 for the different markets considered are illustrated in Graphs 1 to 6 below. We observe a change in the standard deviation dynamics in Graphs 1 (Sherbrooke), 2 (Thetford Mines), and 3 (Victoriaville), as of early 2001, compared to the standard deviation dynamics in Graphs 4 (Montreal-Centre), 5 (MontrealSouth) and 6 (Saint-Hyacinthe).

To test whether the 2001 change in observed dynamics is statistically significant, I carried out two statistical tests. The first, an F-test, compares the variance of standard deviations from 1993 to 2000 to the variance of standard deviations from 2001 to 2006. A second, a t-test, was then conducted to compare the averages of the standard deviations over these two periods. 


\subsection{The collusive city markets}

\section{Graph 1. Dynamics of standard deviation of prices between retailers in Sherbrooke ${ }^{11}$}

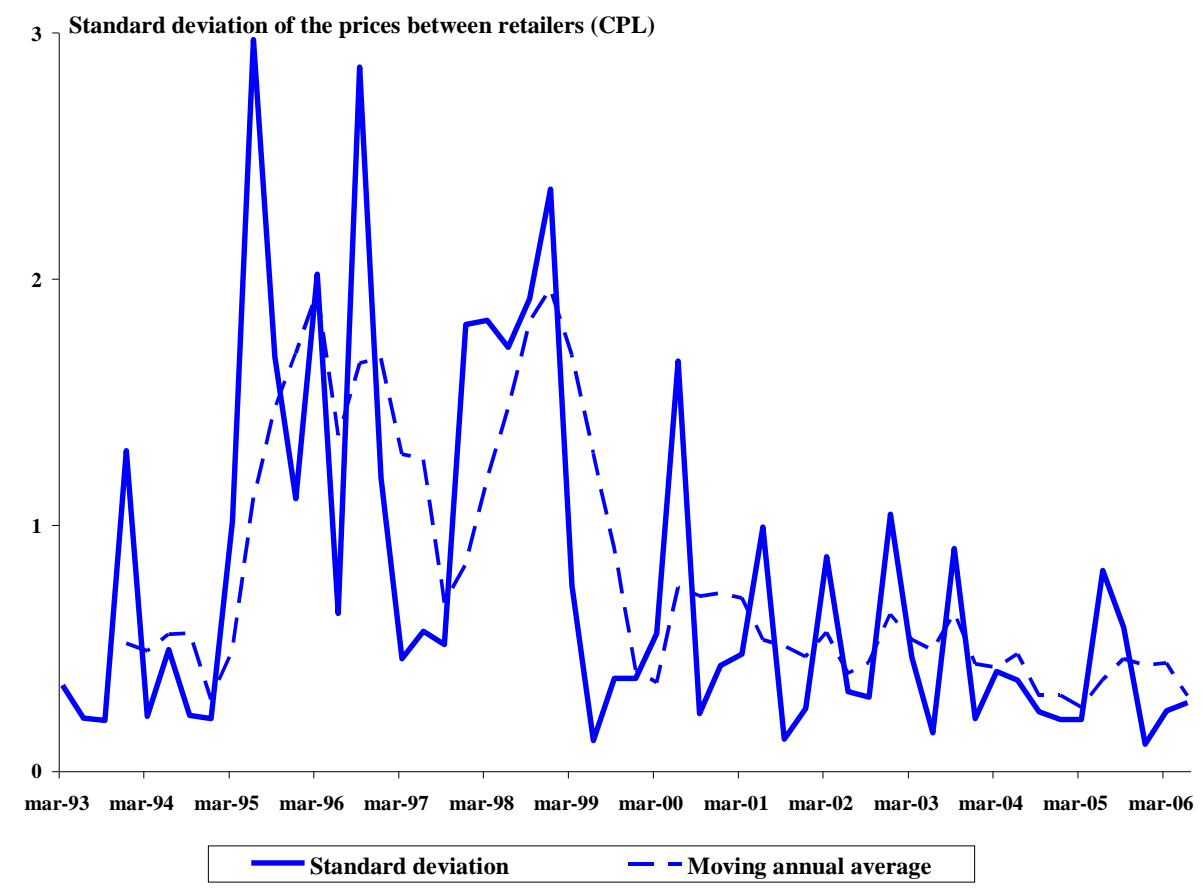

Table 1. Statistical tests on the standard deviation of prices between retailers in Sherbrooke

\begin{tabular}{ccc}
\hline \hline & $1993-2000$ & $2001-2006$ \\
\hline Standard deviation average & $\mathbf{1 . 0 2}$ & $\mathbf{0 . 4 4}$ \\
Standard deviation variance & $\mathbf{0 . 6 9}$ & $\mathbf{0 . 0 9}$ \\
Number of observations & 32 & 22 \\
Average test & & \\
T-statistic value & \multicolumn{2}{c}{3.62} \\
Associated p-value & $\mathbf{0 . 0 0 1}$ \\
Variance test & \multicolumn{2}{|}{7.79} \\
F-statistic value & \multicolumn{2}{c}{$\mathbf{0 . 0 0 0}$} \\
Associated p-value & \multicolumn{2}{c}{} \\
\hline \hline
\end{tabular}

Note: The results in bold represent a statistically significant difference, i.e. for which the p-value is less than 0.05 .

Table 1 shows that the two tests are conclusive: differences between the standard deviation variances and averages are significant. The standard deviation of prices between retailers has gone from an average level of 1.02 CPL before 2001 to 0.44 CPL after 2001, which represents a statistically significant decrease in the price dispersion of more than $50 \%$. We also observe a

\footnotetext{
${ }^{11}$ The moving annual average (dotted line) simply illustrates the average of the last 4 observations, to show a more even and aggregated annual view of the overall dynamics.
} 
statistically significant stabilization, with the standard deviation variance going from 0.69 to 0.09 over the two periods.

\section{Graph 2. Dynamics of standard deviation of prices between retailers in Thetford Mines}

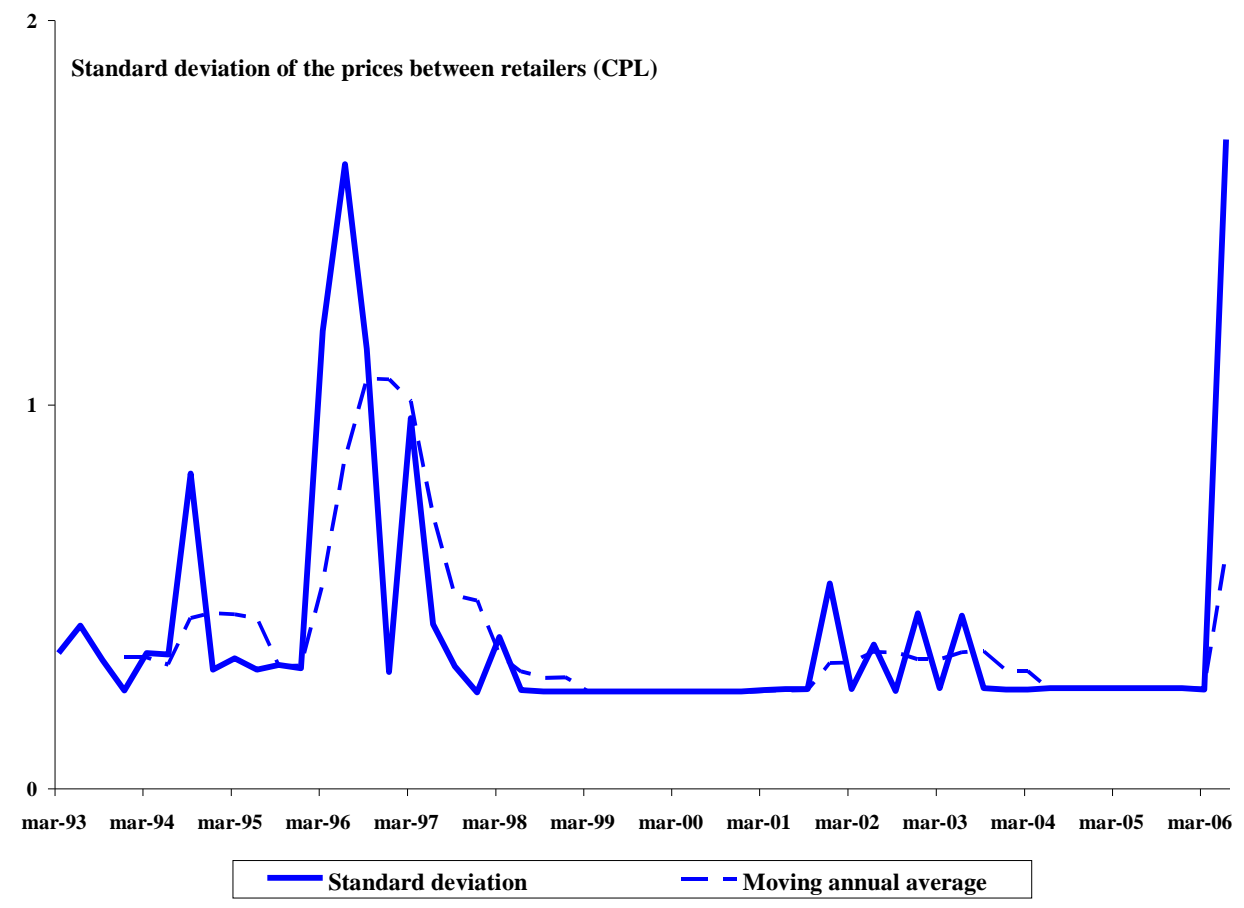

Table 2. Statistical tests on the standard deviation of prices between retailers in Thetford Mines

\begin{tabular}{lcc}
\hline \hline & $1993-1998$ & $1999-2006$ \\
\hline Standard deviation average & 0.49 & 0.33 \\
Standard deviation variance & $\mathbf{0 . 1 4}$ & $\mathbf{0 . 0 7}$ \\
Number of observations & 24 & 30 \\
Mean test & \multicolumn{2}{c}{1.82} \\
$\quad$ T-statistic value & \multicolumn{2}{c}{0.077} \\
$\quad$ Associated p-value & \multicolumn{2}{|}{} \\
Variance test & \multicolumn{2}{c}{1.92} \\
F-statistic value & $\mathbf{0 . 0 4 8}$ \\
Associated p-value & \multicolumn{2}{c}{} \\
\hline \hline
\end{tabular}

Note: The results in bold represent a statistically significant difference, i.e. for which the p-value is less than 0.05 .

Table 2 shows that the average standard deviation of prices between retailers fell from 0.49 CPL for 1993-1999 to 0.33 CPL for 1999-2006 and that, along with this decrease, there was a statistically significant decline in the variance of this standard deviation of prices between retailers, from 0.14 to 0.07 between the two periods. 


\section{Graph 3. Dynamics of standard deviation of prices between retailers in Victoriaville}

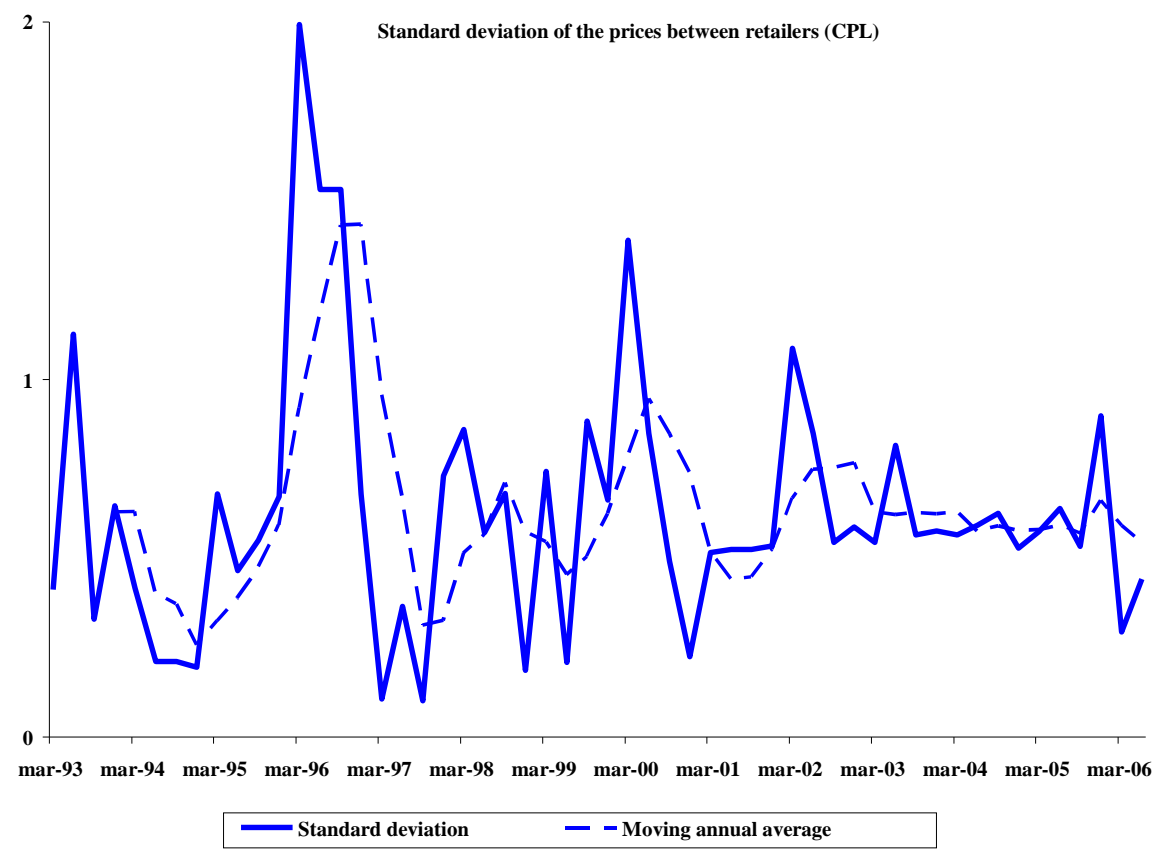

Table 3. Statistical tests on the standard deviation of prices between retailers in Victoriaville

\begin{tabular}{ccc}
\hline \hline & $1993-2000$ & $2001-2006$ \\
\hline Average of standard deviation & 0.65 & 0.61 \\
Variance of standard deviation & $\mathbf{0 . 2 1}$ & $\mathbf{0 . 0 3}$ \\
Number of observations & 32 & 22 \\
Mean test & & \\
T-statistic value & 0.45 & \\
Associated p-value & 0.33 \\
Variance test & \\
F-statistic value & \\
Associated p-value & 7.31 \\
\hline \hline
\end{tabular}

Note: The results in bold represent a statistically significant difference, i.e. for which the p-value is less than 0.05 .

For Victoriaville, a change in price dynamics occurred in early 2001, not in terms of average standard deviation (similar for 1993-2000 and 2001-2006), but in terms of a statistically significant drop in the variance of standard deviations from 0.21 to 0.03 .

Price data for the city of Magog do not allow for a temporal analysis. Suffice it to mention that in the last quarter of 2005 prices were identical for all 13 retailers and, in the first two quarters of 2006, 11 of the 12 retailers listed identical prices. 
To assess the real significance of the trends presented, namely the decrease in standard deviations of prices between retailers and their stabilization after 2001, we must compare them with what happened in other local benchmark markets.

\subsection{The non-collusive city markets}

\section{Graph 4. Dynamics of standard deviation of prices between retailers in Montreal-Centre}

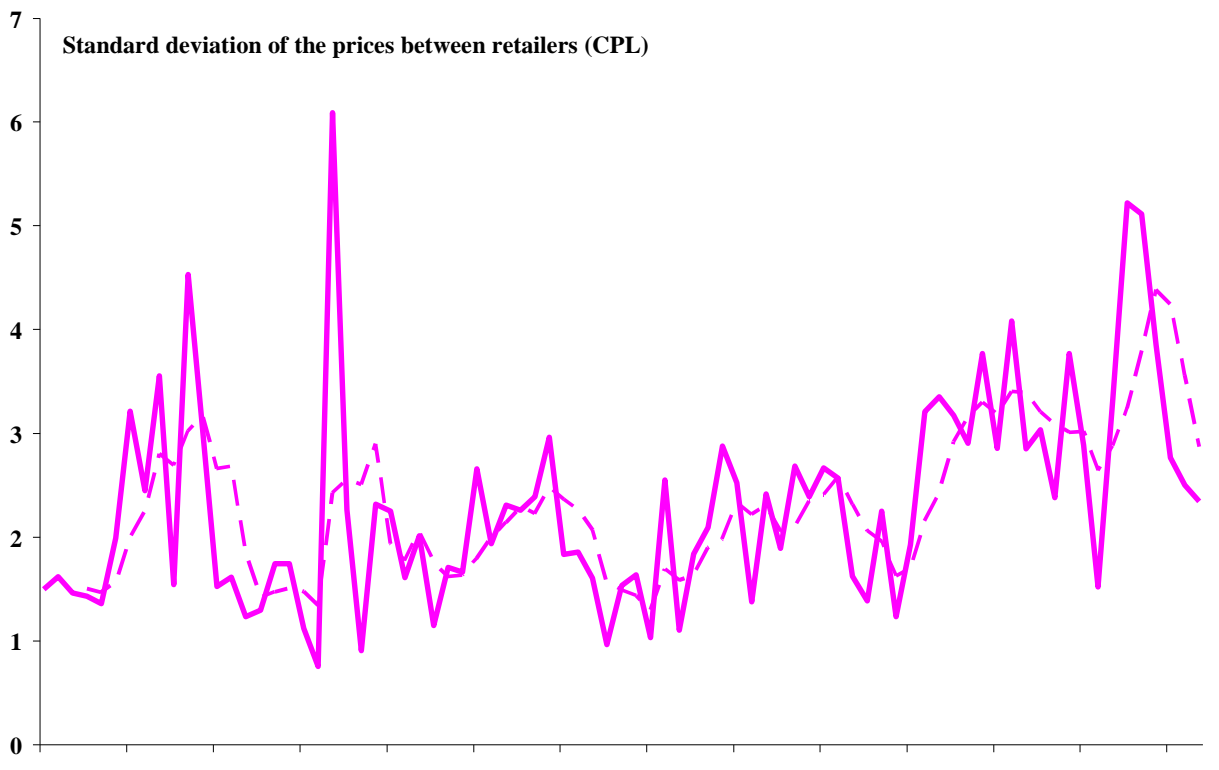

Mar-93 Mar-94 Mar-95 Mar-96 Mar-97 Mar-98 Mar-99 Mar-00 Mar-01 Mar-02 Mar-03 Mar-04 Mar-05 Mar-06

Standard deviation - Moving annual average

Table 4. Statistical tests on the standard deviation of prices between retailers in Montreal-Centre

\begin{tabular}{ccc}
\hline & $1993-2000$ & $2001-2006$ \\
\hline Standard deviation average & $\mathbf{1 . 9 8}$ & $\mathbf{2 . 7 9}$ \\
Standard deviation variance & 0.91 & 0.89 \\
Number of observations & 47 & 34 \\
Mean test & \multicolumn{2}{c}{} \\
T-statistic value & \multicolumn{2}{c}{-3.76} \\
Associated p-value & $\mathbf{0 . 0 0}$ \\
Variance test & \multicolumn{2}{|}{} \\
F-statistic value & \multicolumn{2}{|c}{1.03} \\
Associated p-value & 0.48 \\
\hline \hline
\end{tabular}

Note: The results in bold represent a statistically significant difference, i.e. for which the p-value is less than 0.05 .

Table 4 shows that the average standard deviation of prices between retailers increased from 1.98 CPL for 1993-2000 to 2.79 CPL for 2001-2006, a statistically significant increase (p-value = 0.0003). The volatility of standard deviations decreased slightly from 0.91 to 0.89 , a non- 
significant difference. The dynamics therefore contrast with previously observed trends in collusive cities.

\section{Graph 5. Dynamics of standard deviation of prices between retailers in Montreal-South}

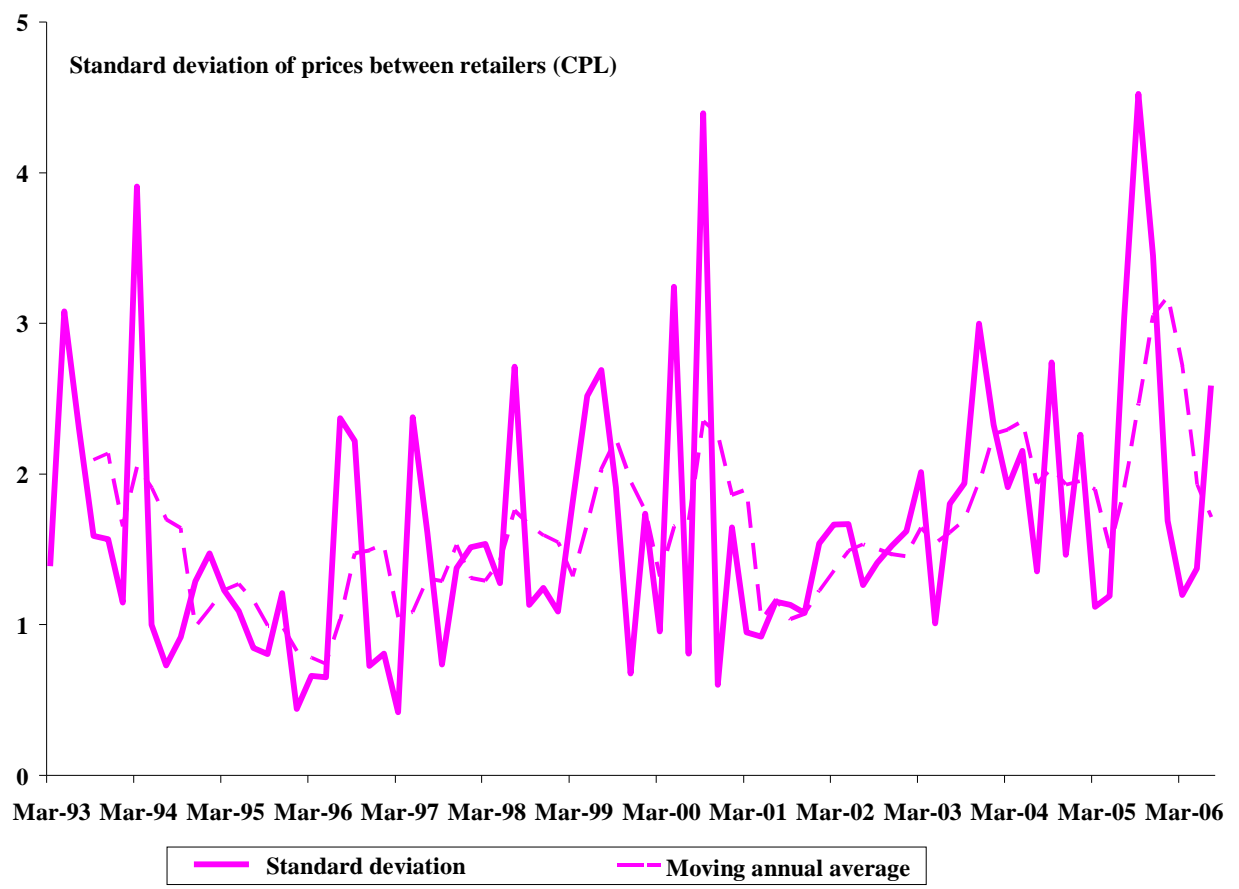

Table 5. Statistical tests on the standard deviation of prices between retailers in Montreal-South

\begin{tabular}{lcc}
\hline \hline & $1993-2000$ & $2001-2006$ \\
\hline Standard deviation average & 1.53 & 1.81 \\
Standard deviation variance & 0.81 & 0.64 \\
Number of observations & 47 & 34 \\
$\quad$ Mean test & \multicolumn{2}{c}{-1.48} \\
$\quad$ T-statistic value & 0.14 \\
$\quad$ Associated p-value & \multicolumn{2}{|}{} \\
$\quad$ Variance test & \multicolumn{2}{c}{1.26} \\
$\quad$ F-statistic value & 0.24 \\
Associated p-value & \multicolumn{2}{c}{0.24} \\
\hline \hline
\end{tabular}

Note: The results in bold represent a statistically significant difference, i.e. for which the p-value is less than 0.05 .

Graph 5 and Table 5 show that the average standard deviation of prices between retailers increased from 1.53 CPL for 1993-2000 to 1.81 CPL for 2001-2006; the variance of standard deviations of prices between retailers decreased from 0.81 to 0.64 . In both cases, the differences are not statistically significant. Again, the dynamics of the standard deviation of prices between retailers contrast with the previously observed trends in cartelized cities. 


\section{Graph 6. Dynamics of standard deviation of prices between retailers in Saint-Hyacinthe}

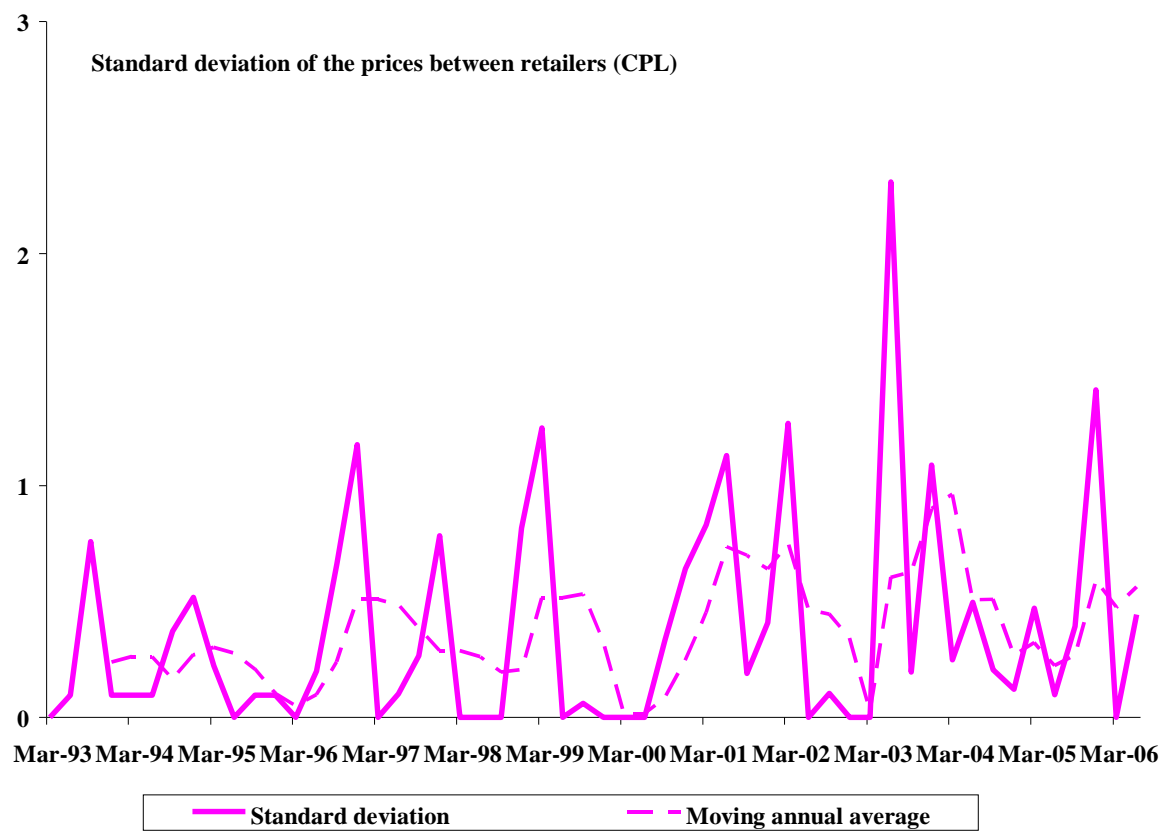

Table 6. Statistical tests on the standard deviation of prices between retailers in Saint-Hyacinthe

\begin{tabular}{lcc}
\hline \hline & $1993-2000$ & $2001-2006$ \\
\hline Standard deviation average & 0.27 & 0.52 \\
Standard deviation variance & $\mathbf{0 . 1 3}$ & $\mathbf{0 . 3 5}$ \\
Number of observations & 32 & 22 \\
Mean test & \multicolumn{2}{c}{} \\
$\quad$ T-statistic value & -1.74 \\
$\quad$ Associated p-value & 0.09 \\
Variance test & \multicolumn{2}{|}{0.37} \\
$\quad$ F-statistic & \multicolumn{2}{c}{0.01} \\
Associated p-value & $\mathbf{0 . 0 1}$ \\
\hline \hline
\end{tabular}

Note: The results in bold represent a statistically significant difference, i.e. for which the p-value is less than 0.05 .

Graph 6 and Table 6 show that the average standard deviation of prices between retailers increased from 0.27 CPL for 1993-2000 to 0.52 CPL for 2001-2006, with a p-value of 0.09. The variance of standard deviations increased from 0.13 to 0.35 , which is a statistically significant increase. Once again, the dynamics of the standard deviation of prices between retailers contrast with the previously observed trends in collusive cities. 


\subsection{Conclusions from the analysis of between-retailer price dispersion}

It appears that Sherbrooke, Thetford Mines, and Victoriaville displayed very special dynamics of price dispersion between retailers, which contrast with the dynamics observed on benchmark markets (Montreal-centre, Montreal-south, and Saint-Hyacinthe).

The between-retailer standard deviations of prices actually decreased significantly in 2001 and remained consistently low afterwards for all cities where collusive activities were shown to exist (wiretaps). Conversely, the between-retailer standard deviations of prices in benchmark markets actually increased after 2001 in a sometimes statistically significant way, and this level of dispersion generally increased over time.

The dynamics of price dispersion in the Sherbrooke, Thetford Mines, and Victoriaville city markets starting in 2001 are consistent with what one would expect in collusive markets. Hence, the data indicate that collusion started in 2001 rather than 2004, which is the year retained by the legal antitrust documents, based on wiretaps covering the 2004-2006 period. The significant drop in the standard deviation of prices across retailers is an indicator, or marker, of the beginning of a cartel.

It is interesting to note that one of the defendants admitted in court that they did indeed begin to fix prices in 2001. In the court case La Reine c. Les Pétroles Global inc. (Cour Supérieure du Québec, chambre criminelle et pénale), Justice Tôth writes in his April 172015 sentencing (following the guilty ruling of August 9 2013): (translation)

"[61] Prof. Boyer observed, from 2001, price dynamics in target markets which contrasted with the reference markets and which could not be explained by local conditions. Collusion was the most plausible explanation, confirmed by investigations and searches by the Competition Bureau.

[62] The evidence at trial, particularly the testimony of Pierre Bourassa, demonstrated that Professor Boyer was right. The collusion started around that time."

If one were to take the period of collusion indicated by the legal proceedings, namely 2004 to 2006, and compare it with the previous presumably non-collusive period 2001-2004, one would find no statistical indication of a price-fixing conspiracy given that collusion already existed during 
the period 2001-2004. Hence the false conclusion would be that no lessening of competition is observed leading to the acquittal of all defendants.

This situation is of course not specific to this case. One can read in the econometrics textbook of the American Bar Association (Econometrics: Legal, Practical, and Technical Issues, $2^{\text {nd }}$ edition, 2014, 443 pages) on page 318:

"When assessing damages using a before-during or a before-during-after approach, the beginning and end points of the damages period must be identified. However, the beginning and the end of the damages period alleged in many cases may not accurately reflect the actual beginning or end of the alleged unlawful conduct. For example, in price-fixing class action cases, the plaintiffs' attorneys often choose the beginning and end dates for the 'class period' before discovery is undertaken. Moreover, the beginning or end of the effects of the alleged unlawful conduct may not coincide with the beginning or end of the conduct itself. The effects might occur later, end earlier, or last longer than the conduct. Experts should rely on the evidence developed in discovery, market facts, and the analysis of liability experts when determining the relevant starting and ending dates for calculating damages." (emphasis added) ${ }^{12}$

\section{Economic impact and damage assessment}

In this section, I will assess whether the evolution of gas prices observed in the cities in question is consistent with the existence of a collusive price-fixing system and whether it allows us to bring to light a quantifiable and statistically significant economic impact on consumer prices.

\subsection{Analysis of observed average prices}

In this section, I contrast the change in the level of observed average price differences in colluding markets with the corresponding values in benchmark markets. To compare prices in different cities, I use the weekly data supplied by the Régie de l'énergie on the average price per city and on the minimum price per region for the 1998-2006 period. As for the benchmark market, I first consider Montreal (centre and south combined), which seems to provide a good baseline for

\footnotetext{
12 The way I used the available data makes the present case a particularly clear and significant example of the ABA recommendation.
} 
formulating a conservative estimate of the economic impact of the price increases eventually observed in the cities we want to analyze. ${ }^{13}$

In order to compare the dynamics of the Régie's average prices for different cities, prices were adjusted to take into account changes in cost dynamics using the Régie's minimum prices. ${ }^{14}$ For example, let's suppose that the average price for regular gasoline is 75 cents in Victoriaville and 72 cents in Montreal. If the minimum price (which is set based on the price per liter, as well as on tax and transportation costs) is 65 cents for Victoriaville and 63 cents for Montreal during the same period, that means that the differences in supply costs justify a 2-cent price difference ( 65 cents v. 63 cents) in favour of Victoriaville. The average price of 75 cents in Victoriaville can therefore be associated with an equivalent average price of 73 cents in Montreal. The cost-adjusted difference in average prices between the two cities is therefore 1 cent ( 73 cents v. 72 cents)

The abrupt change in dynamics, which persisted over many years, is what seems to indicate that systematic price increases occurred in some cities independent of general market trends. These changes in dynamics are more precisely illustrated and statistically tested by a difference-indifferences analysis of prices (adjusted for costs) comparing the two markets over time, expressed in terms of percentages of that city's prices. If we apply this exercise using Montreal as a benchmark city, we tend to see a larger price difference between 2002 and 2005 than before, and this despite the particularly low prices in Montreal at the beginning of this time period.

Graph $7^{15}$ shows the results of a comparison with Montreal for all of the cities involved as a percentage of the pump price in Montreal. The moving average (black line) illustrates the aggregated effect of the four cities we studied and represents the average price difference between these four cities and Montreal over the preceding four quarters.

This increase in the difference of average prices can be statistically tested to verify whether it corresponds to a larger price increase than would be justified by the normal variation rate of this difference. Table 7 shows the average price difference-in-differences between Sherbrooke,

\footnotetext{
${ }^{13}$ Howerver, when using Saint-Hyacinthe as a benchmark, we notice a similar trend.

${ }^{14} \mathrm{I}$, however, only have the minimum prices per region. The price adjustment can consequently not be as precise when specific changes in a city occur (such as, for example, changes in the local taxation rules). Yet, unless there have been measures which could justify price increases, this adjustment is a good indication of the cost changes for retailers in a specific region, especially when we are interested in changes in price dynamics (unexplained increases), rather than differences in levels which are constant over time.

${ }^{15}$ The analysis was also carried out in cents per litre with a similar result.
} 
Victoriaville, Thetford Mines, and Magog on one hand and Montreal on the other, showing that the difference, expressed in percentage of the Montreal pump price, rose from 2.2\% between 1998 and 2000 to $3.5 \%$ between 2001 and 2006, and that this difference is statistically significant (pvalue $=0.02$ ). Therefore, from 2001 to 2006, there was an average aggregate 1.3 percentage point increase in the pump price, relative to Montreal, in these cities taken as a whole.

Graph 7. Dynamics of the average monthly prices per city as compared to the prices in Montreal after adjustment for the cost differences, as a percentage of the pump price in Montreal

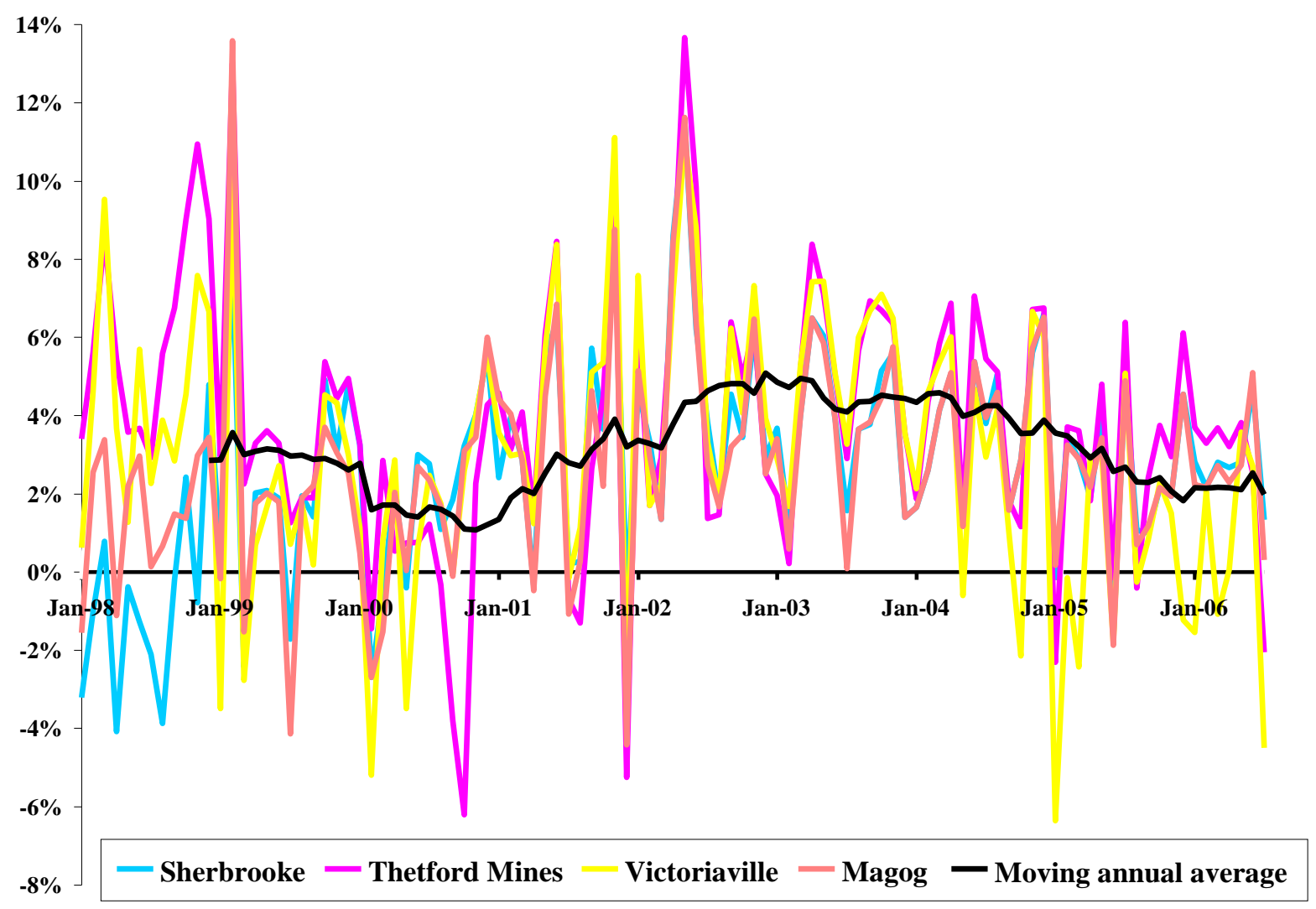

Table 7. Statistical test for the difference between aggregated average prices compared to Montreal, as a percentage of the pump price in Montreal

\begin{tabular}{|c|c|c|}
\hline & $1998-2000$ & $2001-2006$ \\
\hline Average & $2.2 \%$ & $3.5 \%$ \\
\hline Number of observations & 36 & 67 \\
\hline T-statistic value & \multicolumn{2}{|c|}{-2.33} \\
\hline Associated p-value & \multicolumn{2}{|c|}{0.02} \\
\hline
\end{tabular}

Note: The results in bold represent a statistically significant difference, i.e. for which the p-value is less than 0.05 . 
For more precision, we must analyze each city separately in order to assess the economic impact (price increase) associated with it. I will therefore repeat these tests for each cartel city.

Table 7A. Statistical test for the average adjusted price difference between Sherbrooke and Montreal, as a percentage of the pump price in Montreal

\begin{tabular}{|c|c|c|}
\hline & $1998-2000$ & 2001-2006 \\
\hline Average & $1.14 \%$ & $3.51 \%$ \\
\hline Number of observations & 36 & 67 \\
\hline T-statistic value & \multicolumn{2}{|c|}{-4.55} \\
\hline Associated p-value & \multicolumn{2}{|c|}{0.000} \\
\hline
\end{tabular}

Note: The results in bold indicate a statistically significant difference, i.e. for which the p-value is less than 0.05 .

Table 7B. Statistical test for the average adjusted price difference between Victoriaville and Montreal, as a percentage of the pump price in Montreal (until 2005)

\begin{tabular}{|c|c|c|}
\hline & $1998-2000$ & 2001-2004 \\
\hline Average & $2.50 \%$ & $4.45 \%$ \\
\hline Number of observations & 36 & 48 \\
\hline T-statistic value & \multicolumn{2}{|c|}{-2.80} \\
\hline Associated p-value & \multicolumn{2}{|c|}{0.006} \\
\hline
\end{tabular}

Note: The results in bold indicate a statistically significant difference, i.e. for which the p-value is less than 0.05 .

Table 7C. Statistical test for the average adjusted price difference between Magog and Montreal, as a percentage of the pump price in Montreal

\begin{tabular}{|c|c|c|}
\hline & $1998-2000$ & 2001-2006 \\
\hline Average & $1.74 \%$ & $3.29 \%$ \\
\hline Number of observations & 36 & 67 \\
\hline T-statistic value & \multicolumn{2}{|c|}{-2.79} \\
\hline Associated p-value & \multicolumn{2}{|c|}{0.006} \\
\hline
\end{tabular}

Note: The results in bold indicate a statistically significant difference, i.e. for which the p-value is less than 0.05 .

In Sherbrooke, the price difference adjusted for cost differences went from $1.14 \%$ to $3.51 \%$, a significant increase $(\mathrm{p}=0.000)$ representing $2.37 \%$ of the pump price in Montreal—and similarly for Victoriaville and Magog.

The case of Thetford Mines is more complex. Indeed, the previous analysis showed a marked downward trend and a stabilization of the price dispersion between retailers, starting as early as 1998. However, the data of the Régie de l'énergie is not available before 1998 and it is therefore impossible for us to perform a price difference-in-differences analysis adjusted for differences in costs between Thetford Mines and Montreal (or any other reference city) before and after 1998. 
In Victoriaville, from January 2001 to December 2004, the relative price increase as compared to Montreal is statistically significant $(\mathrm{p}=0.006),{ }^{16}$ with the average price difference going from $2.50 \%$ to $4.45 \%$, which is a 1.95 percentage point increase in the pump price during that period.

For Magog, there is not enough data per retailer to allow us to analyze the price dispersion dynamics between retailers, so we cannot estimate how long any potential collusion might have lasted. However, there was a small increase in average monthly prices in Magog in comparison with those in Montreal, starting in 2001—after adjustment for cost differences. This 1.56 percentage point increase in the pump price is statistically significant $(p=0.006)$ for the city of Magog.

As mentioned before, Montreal appears to provide a good baseline for conservative estimates of the relative price increases observed in cities where collusion did take place (wiretaps). However, other reference cities could also be used. Choosing these cities is not an easy task, since the cities must be representative of the market, must not be involved in price fixing activities and, if possible, have a market structure resembling those of the cartel cities.

Saint-Hyacinthe appears to provide a good benchmark. As we have seen, its price dynamics appear relatively similar to those of Montreal, despite its smaller size and geographical location. The price dispersion between its retailers does not seem to systematically decrease over the time period of interest. In what follows we will detail all of the analyses presented above, using Saint-Hyacinthe, instead of Montreal, as the benchmark city. These results are presented without detailed comments since they support the results obtained using Montreal as a reference city, with the relative price increases appearing to be larger and statistically more significant. This is essentially due to the fact that gasoline in Montreal appears to be relatively inexpensive at the beginning of the sample.

\footnotetext{
${ }^{16}$ Between 2001 and 2006 however, these numbers do not show a statistically significant difference, which is easy to understand since the lower price level (more intense competition due to the breakdown of the cartel) started again in 2005 .
} 
Graph 8. Dynamics of the average monthly prices per city, in comparison to the prices in Saint-Hyacinthe after adjustment for cost differences, as a percentage of the pump price in Saint-Hyacinthe

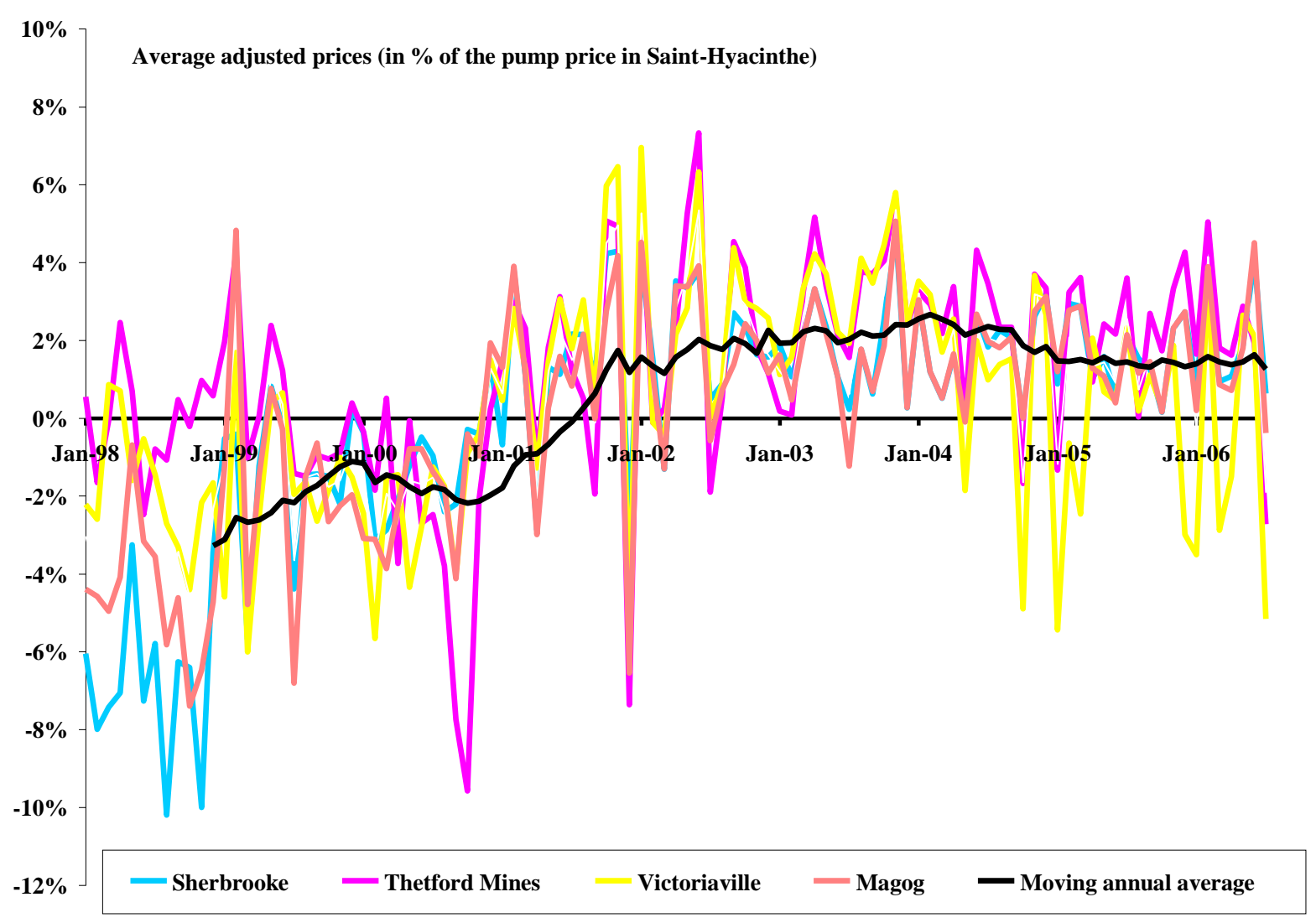

We therefore notice that, when Saint-Hyacinthe is used as a benchmark city, the average monthly adjusted price difference in Sherbrooke goes from $-1.95 \%$ between 1998 and 2000 to $+1.43 \%$ between 2001 and 2006, which is a statistically significant increase of 3.38 percentage points of the pump price in Saint-Hyacinthe. Thetford Mines showed a 2.54 percentage points increase during this same time period; Victoriaville showed a 2.33 percentage points increase and Magog, a 2.92 percentage point increase. All of these increases are statistically significant.

Table 8. Statistical test for the difference of aggregated average prices compared to SaintHyacinthe, as a percentage of the pump price in Saint-Hyacinthe

\begin{tabular}{lcc}
\hline \hline & $1998-2000$ & $2001-2006$ \\
\hline Average & $\mathbf{- 1 . 4 \%}$ & $\mathbf{1 . 4 \%}$ \\
Number of observations & 36 & 67 \\
T-statistic value & \multicolumn{2}{c}{-11.09} \\
Associated p-value & $\mathbf{0 . 0 0 0}$ \\
\hline \hline
\end{tabular}

Note: The results in bold indicate a statistically significant difference, i.e. for which the p-value is less than 0.05 . 
Table 8A. Statistical test for the average adjusted price difference between Sherbrooke and Saint-Hyacinthe, as a percentage of the pump price in Saint-Hyacinthe

\begin{tabular}{ccc}
\hline \hline & $1998-2000$ & $2001-2006$ \\
\hline Average & $-\mathbf{1 . 9 \%}$ & $\mathbf{1 . 4 \%}$ \\
Number of observations & 36 & 67 \\
T-statistic value & & -10.20 \\
Associated p-value & \multicolumn{2}{c}{$\mathbf{0 . 0 0 0}$} \\
\hline \hline
\end{tabular}

Note: The results in bold indicate a statistically significant difference, i.e. for which the p-value is less than 0.05 .

Table 8B. Statistical test for the average adjusted price difference between Thetford Mines and Saint-Hyacinthe, as a percentage of the pump price in Saint-Hyacinthe

\begin{tabular}{ccc}
\hline \hline & $1998-2000$ & $2001-2006$ \\
\hline Average & $-\mathbf{0 . 7 \%}$ & $\mathbf{1 . 8 \%}$ \\
Number of observations & 36 & 67 \\
T-statistic value & & -6.58 \\
Associated p-value & \multicolumn{2}{c}{$\mathbf{0 . 0 0 0}$} \\
\hline \hline
\end{tabular}

Note: The results in bold indicate a statistically significant difference, i.e. for which the p-value is less than 0.05 .

Table 8C. Statistical test for the average adjusted price difference between Victoriaville and Saint-Hyacinthe, as a percentage of the pump price in Saint-Hyacinthe

\begin{tabular}{|c|c|c|}
\hline & $1998-2000$ & 2001-2006 \\
\hline Average & $-1.3 \%$ & $1.1 \%$ \\
\hline Number of observations & 36 & 67 \\
\hline T-statistic value & \multicolumn{2}{|c|}{-6.76} \\
\hline Associated p-value & \multicolumn{2}{|c|}{0.000} \\
\hline
\end{tabular}

Note: The results in bold indicate a statistically significant difference, i.e. for which the p-value is less than 0.05 .

Table 8D. Statistical test for the average adjusted price difference between Magog and SaintHyacinthe, as a percentage of the pump price in Saint-Hyacinthe

\begin{tabular}{ccc}
\hline \hline & $1998-2000$ & $2001-2006$ \\
\hline Average & $-\mathbf{1 . 7 \%}$ & $\mathbf{1 . 3 \%}$ \\
Number of observations & 36 & 67 \\
T-statistic value & & -9.90 \\
Associated p-value & & $\mathbf{0 . 0 0 0}$ \\
\hline \hline
\end{tabular}

Note: The results in bold indicate a statistically significant difference, i.e. for which the p-value is less than 0.05 .

To support my contention that the effects observed during the course of these analyses are not dependent on my sample of benchmarks, I selected three other cities which are of interest because 
of their geographical location, their size and the breadth of their market: Trois-Rivières, Drummondville and Québec city.

The first two cities yielded results similar to those found with Montreal and Saint-Hyacinthe as benchmarks. For Québec City, we did not find the same trends because its pump prices had also greatly increased in comparison to those in Montreal after 2000. The effect of the relative price increase observed in comparison to Montreal and to other benchmark cities was therefore counterbalanced by the price increase in Québec City. A quick review of the literature on the gasoline market in Québec City led me to discover that a major price war took place in Québec City during this period, ${ }^{17}$ followed by a price correction around $2001 .{ }^{18}$ It is for that reason that comparing the relative price changes of the cities studied with Québec City would yield a biased and misleading economic impact assessment.

\subsection{Estimation of damages}

Estimating damages due to cartel activity has always been a challenging task. Even in cases where a cartel is found guilty by the court, fines imposed in accordance with the applicable guidelines are primarily a deterrence tool rather than an estimate of harms or damages caused by the cartel. ${ }^{19}$ For instance, the European Commission Fining Guidelines ${ }^{20}$ considers the proportion of sales of goods or services to which the infringement relates, multiplied by the duration of the infringement, "an appropriate proxy to reflect the economic importance of the infringement as well as the relative weight of each undertaking in the infringement," which can reach $30 \%$ of sales plus or minus some aggravating or mitigating factors. Hence the fine is not directly related

\footnotetext{
17 "Les guerres de prix entre les stations d'essence dans la région de Québec en 2000 : signe d'anomalie au fonctionnement du marché ?" Study carried out by Christos Constantatos for CAA-Québec www.green.ulaval.ca/guerres.pdf.

${ }^{18}$ In 2000, the profit margins had become so low in Québec City that the Régie de l'énergie accepted an addition of 3 cents per litre on the price during a period of 3 months as requested by the retailers in December 2000. See “Analyse des impacts de l'exercice des pouvoirs de la Régie de l'énergie sur les prix et les pratiques commerciales de la vente au détail d'essence ou de carburant diesel." Rapport de la Régie de l'énergie au ministre des Ressources naturelles, de la Faune et des Parcs du Québec. June 2004. www.bibliotheque.assnat.qc.ca/01/PER/794146/2004.pdf.

${ }^{19}$ Boyer, M., Faye, A.C., Gravel, É., Kotchoni, R., "Challenges and Pitfalls in Cartel Fining," Canadian Competition Law Review 31(1), September 2018, 50-82.

${ }^{20}$ The European Commission Fining Guidelines are described in Guidelines on the method of setting fines imposed pursuant to Article 23(2)(a) of Regulation No 1/2003. Fining rules are similar in other jurisdictions.
} 
to the value of harms and damages caused. The reason is that estimating such harms and damages is very difficult.

In the present case, damages were estimated as follows. The data per retailer supplied by Kent Marketing not only gives us the prices, but also the volumes of gasoline sold per retailer during the months since the last price reading. We can therefore aggregate these volumes to get a precise annual estimate for the volumes sold in each city.

Multiplying these volumes by the incremental price differential observed in comparison to the benchmark city during the period for which collusion is presumed as compared to the usual differential during the period before the collusion appeared (the difference in differences) gives us an estimate of the annual damages incurred by consumers in each of the affected cities.

This estimated overcharge is consequently based on the chosen benchmark city. In our analysis, we saw that the incremental difference is generally lower when Montreal is used as a benchmark and higher when Saint-Hyacinthe is used, primarily because the prices listed in Montreal are particularly low at the end of 1998 during the Asian economic crisis. The reported estimates of economic damages for these two reference cities show the breadth of the economic impact as well as the sensitivity of this estimate to the choice of the benchmark city.

Moreover, we should note that choosing January 2001 as starting date for the collusion is, of course, somewhat arbitrary. It seems more likely that the quick and continued price increase in 2000 and 2001, after the 1999 Asian economic crisis and before the 2001 economic crisis, led to increased communication between retailers seeking to standardize price variations in periods of great volatility. These relations were maintained afterwards, which helped to maintain the artificial price increases over the next few years. The collusion and price fixing phenomena were certainly progressive, yet they seem to have become systematic as of early 2001 and were particularly noticeable from 2002 to the end of 2004.

In this analysis, I will separately estimate the economic impact by city and by year in order to fully account for variations in the scope of the potential effect of collusion activities over time, and to couple it to the relative volumes sold over these years.

This analysis brings together information from many sources, the annual average prices for the benchmark cities calculated using the data supplied by the Régie de l'énergie, the annual price 
differences adjusted for costs (for taxes and transportation), as provided by the Régie, and gasoline volumes sold in each of the cities, aggregated from data per retailer provided by Kent Marketing. Moreover, all of the estimates are based on regular gas price volumes only. In our sample, this always makes up more than $80 \%$ of the gasoline bought and sold, so the estimation of the economic impact based on this data is an underestimate of the total impact.

Since the volumes for Magog are only available for one quarter in 2005 and two quarters in 2006, the volumes for the other years were extrapolated on the assumption that they followed the same temporal dynamics as those in Sherbrooke, the closest available city.

For the city of Thetford Mines, determining the period of the collusion and the relative price increase during this period is tricky since my analysis indicates that the price fixing system was in place since the beginning of the time period for which I am able to compare prices between cities. I therefore do not have data for a period of time preceding the collusion, from which I could have obtained an estimate of the incremental price increase. In this context, a conservative estimation, underestimating the extent of the damages, can however be obtained as follows. If we suppose that the period during which the large price increase which followed the Asian crisis could dampen the effects of existing collusion, ${ }^{21}$ we can use the period 1998-2000 as a temporal no-cartel reference and the "abnormal" price differentials of 2001-2006 as an indication of the extent of the price surcharge, as the difference-in-differences, that retailers in Thetford Mines were generally able to maintain. This imperfect measurement gives us a lower bound estimate of the economic impact of the cartel. Data in Tables 9 and 10 correspond to these lower bound estimates.

Estimated damages are reported in Table 9 for the period 2001-2006 and Table 10 for the period 2004-2006.

[Insert Table 9]

[Insert Table 10]

For a better idea on how damages were calculated, let me break down the amount of $\$ 1,353,244$ for the city of Sherbrooke in 2005 (Table 9). The calculation of damages is as follows: How much lower would the value of sales in Sherbrooke be if the selling price had been the same as its

\footnotetext{
${ }^{21}$ We observe a relative price correction in Thetford Mines in comparison to Montreal and in comparison to SaintHyacinthe during this time period.
} 
historical in Montreal, adjusted for regional differences in taxation and operating costs? This value differential is precisely $\$ 1,353,244$. Hence, gasoline buyers in Sherbrooke, in 2005, were prejudiced in the amount of $\$ 1,353,244$. To calculate this type of damages, a few intermediate numbers need to be obtained. First of all, I need to know the historical price difference between Montreal and Sherbrooke adjusted for differences in taxation and other costs before the alleged collusion. For this, I take the average of the adjusted price differences in percentages between Sherbrooke and Montreal for the years 1998 to 2000. This average comes to $1.1 \%$. That means that, historically, prices were 1.1\% higher in Sherbrooke than in Montreal. In 2005, I calculated that this difference was $2.2 \%$, or 1.1 percentage points higher than the normal historical difference, which is the difference-in-differences. Therefore, prices in the Sherbrooke region were 1.1 percentage point higher than their normal level, when using Montreal as a baseline. Knowing that the average gas price in Montreal in 2005 was $\$ 0.974$, I can calculate the overcharge, in cents per litre, that Sherbrooke customers paid for their gasoline. That comes to $\$ 0.01$ per litre $(\$ 0.974 *$ $1.1 \%){ }^{22}$ Gas customers in Sherbrooke paid 1 cent per litre extra for each litre bought in 2005. Since they bought $135,277,507$ litres in 2005 , the amount of damages comes to $\$ 0.010003 *$ $135,277,507$ litres, which gives us an amount of $\$ 1,353,244$.

Let's do the same thing for two other amounts from Table 9. Consider first the amount of damages for Victoriaville in 2006. Historically, the difference between Victoriaville and Montreal was 2.8\% whereas in 2006 the difference was 1\%. Consequently, in 2006, in Victoriaville, prices were 1.8 percentage point lower than their historical value when Montreal is the benchmark city. During this period, there was a breakdown in the efficiency of the collusion (price war?) and so no cost due to collusion is estimated to have been incurred. The damages come to $\$ 0$.

\footnotetext{
${ }^{22}$ These results are quite far from the overcharges reported in Connor and Lande (2008) who found a mean overcharge estimate in the range of $31 \%$ to $49 \%$. By examining more sources, Connor (2010) finds a mean of $50.4 \%$ for successful cartels. However, the data used in those studies are estimates obtained from different methodologies, sources and contexts rather than from direct observations. Therefore, these data are subject to model error, estimation error, endogeneity bias, and publication bias. Boyer and Kotchoni (2015) performed a close examination of the Connor database (some 1120 cartels), which revealed that the universe of overcharge estimate is asymmetric and heterogenous, containing a number of influential observations. Beside the fact that overcharge estimates are potentially biased, fitting a linear regression model to the data without providing a careful treatment of the problems raised above may produce distorted results. Boyer and Kotchoni conducted a meta-analysis of cartel overcharge estimates in the spirit of Connor and Bolotova (2006) while providing a sound treatment of these matters. They found bias-corrected mean and median overcharge estimates of $15.5 \%$ and $16.0 \%$.
} 
Consider now the amount $\$ 6,368,861$ for the damages in Sherbrooke in 2005. Historically, the price difference between Sherbrooke and Saint-Hyacinthe was $-3.2 \%$ whereas in 2005 it was $1.7 \%$. So, in 2005, prices in Sherbrooke were 1.7\% $-(-3.2 \%))=4.9$ percentage point higher than their historical value when Saint-Hyacinthe is the benchmark city. Hence, the cartel markup comes out to be $\$ 0.973 * 4.9 \%=4.8$ cents per litre. By applying this difference to the volume of regular gas bought and sold in Sherbrooke in 2005, we get \$0.04708* 135277507 litres, which comes to a total amount of $\$ 6,368,861$.

We therefore get an estimate of the economic impact of relative price increases (Table 9) which, for the period 2001 to 2006 jump from $\$ 14.3 \mathrm{M}$ to $\$ 30.7 \mathrm{M}$ for Sherbrooke, from $\$ 592.3 \mathrm{~K}$ to $\$ 2.5 \mathrm{M}$ for Thetford Mines, from $\$ 2.2 \mathrm{M}$ to $\$ 5.0 \mathrm{M}$ for Victoriaville and from $\$ 1.4 \mathrm{M}$ to $\$ 3.7 \mathrm{M}$ for Magog. Globally, for these four cities, the damages caused by collusion amount to a total of between $\$ 18.5 \mathrm{M}$ and $\$ 42.0 \mathrm{M}$.

For the years 2004 to 2006, the period covered by the lawsuits filed by the public prosecutor, the estimation of damages (Table 10) ranges from $\$ 5.8 \mathrm{M}$ to $\$ 15.9 \mathrm{M}$ for Sherbrooke, from $\$ 153.5 \mathrm{~K}$ to $\$ 1.3 \mathrm{M}$ for Thetford Mines, from $\$ 247.8 \mathrm{~K}$ to $\$ 1.6 \mathrm{M}$ for Victoriaville and from $\$ 513.8 \mathrm{~K}$ to $\$ 2.0 \mathrm{M}$ for Magog. Globally, for these four cities, the damages caused by collusive activities amount to an estimated total ranging from $6.7 \mathrm{M} \$$ to $20.9 \mathrm{M} \$$.

\section{Some related literature}

For comparison purposes, it is interesting to note that Wang (2008) described in detail the collusion dynamics and the phenomenon of price increases in a cartel case involving gas stations in Australia. Among other things, he had at his disposal 90 days worth of information on calls between retailers and the corresponding price variations to identify the scale of the artificial price increases that took place. He isolated 16 "successful" price increases over a period of 90 days. Wang also estimated that the price increases were, on average, 6.9 Australian cents per litre (which is approximately 6.3 Canadian cents per litre). If we aggregate this information by supposing, for example, that these artificial increases diminished and disappeared over 3 days following their implementation, we get an average increase of $2.24 \mathrm{CPL}$ (in Canadian dollars) over the time period studied. This average increase is similar to my estimations here, which varies between 1 and 5 CPL, depending on the city and on the year. 
Erutku and Hildebrand (2010), using a difference-in-differences approach for the period June 2005 to May 2007 spanning one year before and one year after the announcement of the investigation by the Competition Bureau, derive a statistically significant price reduction in Sherbrooke of 1.75 CPL post-announcement, which translates into two million dollars in damages for the last year of the conspiracy.

Clark and Houde $(2013,2014)$ provide a fascinating and detailed analysis of the internal working of the Quebec gasoline cartel, that is, the explicit mechanisms that were used by participants to obtain the allegiance of a large majority of station operators and to prevent defections. Given the heterogeneity of gas stations, both in term of size and services provided, some form of transfer from weaker to stronger members of the cartel had to be imagined and executed. Those transfers originated through delayed price increases and decreases across participants favoring stronger players, generating short-term price discrepancies lasting a few minutes and yielding significant benefits to late movers. This set of peculiar mechanisms appear well suited for collusion in markets where price posting is the norm.

\section{Conclusion}

The results obtained through descriptive analyses and regression analyses are consistent with a presumption of collusion in the cities of Magog, Sherbrooke, Thetford Mines and Victoriaville. Indeed, the volatility level of price variation between retailers in cartel cities shows very particular dynamics, which appear to be contrary to economic common sense and to dynamics observed in non-cartel cities of Montreal Centre, Montreal South, and Saint-Hyacinthe. Prices per retailer from 1993 to 2006 clearly highlight a price convergence which started both with a decrease and stabilization of between-retailer price volatility starting in 2001 in Sherbrooke and Victoriaville, and in 1998 in Thetford Mines. For the benchmark cities, on the contrary, the price volatility between retailers is either stable or on the rise. This is consistent with a presumption of collusion and price fixing activities in cartel cities during these periods, as direct contact between retailers favours a convergence towards the collusive price, while the search for a new equilibrium in a competitive market goes through a trial and error process.

Independent gas stations have no market power, but gas stations that are united by a price fixing agreement, as identified in the wiretap evidence, have a great deal of market power, as we see in all four cartel markets studied. Indeed, the market shares of the gas stations for which we have 
direct or indirect proof of participation in the cartel reaches 92\% (2006) in Magog, 89\% (2005) and 87\% (2006) in Sherbrooke, 93\% (2005 and 2006) in Thetford Mines, 98\% (2005), and 99\% (2006) in Victoriaville.

As for the impact of these activities on the gas prices to customers, comparative price level analyses through a difference-in-differences analysis make it clear that there was a relative price increase in these cartel cities, in comparison to the reference cities, during these periods of lower price divergence between retailers previously singled out - even after adjusting for differentials in intertemporal cost fluctuations. For Sherbrooke and Magog, these relative price differences systematically appear and are statistically significant for the entire post 2001 period. This period corresponds to the one for which we see a decrease and a significant stabilization of the price divergence between retailers, confirming that the two phenomena are linked. For Victoriaville, the results are similar except that the price increase slows down during 2005, a sign that the cartel may have encountered some difficulty due to the market's high volatility that year. For Thetford Mines, the available data does not allow us to isolate a difference-in-differences in prices as the data indicates that the cartel starting date was 1998, which corresponds to the beginning of our complete price data sample.

These relative price increases during the periods for which we observed decreases and stabilizations in the price dispersion between retailers allow us to make a global estimate of the economic impact of cartel price fixing operations. The global damages of the cartel for the four cities considered amount to a total between 18.5M and 42.0M\$ for the period 2001-2006. For the period 2004-2006, the global damage estimate is between $\$ 6.7 \mathrm{M}$ and $\$ 20.9 \mathrm{M}$.

The fact that the collusion period 2001-2006 identified by my data analysis was confirmed in court by one or the defendants and the fact that my economic analysis and results of the cartel impact was uncontested in criminal court as, besides vigorous counter-interrogation, no counter analysis, expert reports, or expert testimonies were provided by legal defense teams are, I believe, telling. 


\section{References}

Abrantes-Metz, R.M., L.M. Froeb, and C.T. Taylor. (2004) "Variance and Smoothness Screens for Collusion," Presented at the International Industrial Organization Conference, Chicago, Illinois (draft of April 9, 2004).

American Bar Association (2014), Econometrics: Legal, Practical, and Technical Issues, $2^{\text {nd }}$ edition, 443 pages.

Boyer, M. (2007/2008), “Collusion présumée des essenceries de plusieurs villes du Québec : analyse de données et évaluation d'impact économique", Bureau de la Concurrence du Canada, 23 juillet 2008, 126 pages.

Boyer, M., A.C. Faye, É. Gravel, and R. Kotchoni (2018), "Challenges and Pitfalls in Cartel Fining," Canadian Competition Law Review 31(1), 50-82.

Boyer, M. and R. Kotchoni (2015), "How Much do Cartels Overcharge?", Review of Industrial Organization 47(2), 119-153.

Boyer, M., T.W. Ross, and R.A. Winter (2017), “The Rise Of Economics In Competition Policy: A Canadian Perspective", Canadian Journal Of Economics 50(5), 50 ${ }^{\text {th }}$ Anniversary Issue, 14891524.

California Energy Commission, MTBE Phase Out in California Consultant Report, Publication 600-02-008CR, 2002. www.energy.ca.gov/reports/2002-03-14_600-02-008CR.PDF

Clark, R, and J.F. Houde (2013), "Collusion with Asymmetric Retailers: Evidence from a Gasoline Price-Fixing Case,” American Economic Journal: Microeconomics 5(3), 97-123.

Clark, R, and J.F. Houde (2014), "The Effect of Explicit Communication on Pricing: Evidence from the Collapse of a Gasoline Cartel," The Journal of Industrial Economics LXII(2), 191-228.

Connor, J.M. (2005), “Collusion and Price Dispersion,” Purdue University, Available at SSRN: https://ssrn.com/abstract=787849 or http://dx.doi.org/10.2139/ssrn.787849

Connor, J.M. (2010). Price-fixing Overcharges, $2^{\text {nd }}$ Edition (available online at http://papers.ssrn.com/sol3/papers.cfm?abstract_id=1610262)

Connor, J.M. (2014). Price-fixing Overcharges. The Law and Economics of Class Actions: Research in Law and Economics, Volume 26, 249-387

Connor, J.M. and Y. Bolotova (2006), “A Meta-Analysis of Cartel Overcharges,” International Journal of Industrial Organization 24: 1109-1137

Connor, J.M. and R.H. Lande (2008). Cartel Overcharges and Optimal Cartel fines. Issues in Competition Law and Policy, S.W. Waller (ed.), Volume 3, AMA Section of Antitrust Law, chapter 88, pp. 2203-2218.

Constantatos, C. (2001), Les guerres de prix entre les stations d'essence dans la région de Québec en 2000 : signe d'anomalie au fonctionnement du marché?, Étude pour CAA-Québec http://www.regie-energie.qc.ca/audiences/3457-00/Preuveetmemoires/Caa/Preuve-21fev.pdf

Dahl, C.A. and T. Sterner (1991), “Analyzing Gasoline Demand Elasticities: A Survey,” Energy Economics 13(3): 203-210. 
Erutku, C. and V.A. Hildebrand (2010), "Conspiracy at the Pump," Journal of Law and Economics 53, 223-237.

Fanaki, A. (2010), "Recent Reforms to Canada's Competition Act: The First Year (and a Half)", The Canadian Bar Association Annual Fall Conference http://www.cba.org/cba/cle/PDF/COMP10_Fanaki_paper.pdf

Fink, N., P. Schmidt-Dengler, K. Stahl, and C. Zulehner (2015), "Registered Cartels in Austria An Overview," mimeo, December 2015 - ZEW Discussion Papers 14-058

Harrington, J.E.Jr. (2006), “How Do Cartels Operate?”, Foundations and Trends in Microeconomics 2(1), 1-105.

Régie de l'Énergie du Québec (2004), Analyse des impacts de l'exercice des pouvoirs de la Régie de l'énergie sur les prix et les pratiques commerciales de la vente au détail d'essence ou de carburant diesel, (Analysis on the impact of the Régie de l'énergie's power over gasoline or diesel prices and commercial practices). www.bibliotheque.assnat.qc.ca/01/PER/794146/2004.pdf.

Tirole, J. (1988), The Theory of Industrial Organization, Cambridge, MA: M.I.T Press.

Wang, Z. (2008), "Collusive Communication and Pricing Coordination in a Retail Gasoline Market," Review of Industrial Organization, 32(1), 35-52. 
Table 9. Estimate of the economic damages due to overcharges by city and year (2001-2006) with respect to benchmark cities Montréal and Saint-Hyacinthe

\begin{tabular}{|c|c|c|c|c|c|c|c|c|c|c|}
\hline City & Variable & 1998 & 1999 & 2000 & 2001 & 2002 & 2003 & 2004 & 2005 & $2006^{*}$ \\
\hline Montréal & Price (Régie) & 55.8 & 63.3 & 77.3 & 73.7 & 71.6 & 76.3 & 85.4 & 97.4 & 103.9 \\
\hline Saint-Hyacinthe & Price (Régie) & 57.6 & 64.1 & 78.2 & 73.8 & 73.0 & 77.2 & 86.5 & 97.3 & 104.1 \\
\hline Sherbrooke & Volumes & $130,400,331$ & $123,127,718$ & $126,571,318$ & $130,504,228$ & $137,612,137$ & $136,390,077$ & $135,557,643$ & $135,277,507$ & $68,213,375$ \\
\hline Sherbrooke & Price differential wrt Montréal & $-0.7 \%$ & $2.2 \%$ & $1.9 \%$ & $3.2 \%$ & $4.9 \%$ & $3.9 \%$ & $3.8 \%$ & $2.2 \%$ & $3.0 \%$ \\
\hline Sherbrooke & Price differential wrt Saint-Hyacinthe & $-6.8 \%$ & $-1.5 \%$ & $-1.2 \%$ & $1.2 \%$ & $2.0 \%$ & $1.8 \%$ & $1.8 \%$ & $1.7 \%$ & $2.1 \%$ \\
\hline Thetford Mines & Volumes & $16,663,486$ & $17,036,094$ & $16,289,432$ & $17,618,087$ & $17,858,259$ & $17,824,594$ & $17,830,695$ & $17,750,979$ & $7,999,771$ \\
\hline Thetford Mines & Price differential wrt Montréal & $6.2 \%$ & $4.0 \%$ & $0.3 \%$ & $3.1 \%$ & $5.4 \%$ & $5.0 \%$ & $4.5 \%$ & $2.7 \%$ & $3.4 \%$ \\
\hline Thetford Mines & Price differential wrt Saint-Hyacinthe & $0.0 \%$ & $0.3 \%$ & $-2.8 \%$ & $1.1 \%$ & $2.5 \%$ & $2.9 \%$ & $2.5 \%$ & $2.2 \%$ & $2.5 \%$ \\
\hline Victoriaville & Volumes & $40,694,195$ & $41,441,588$ & $43,962,601$ & $43,021,184$ & $43,637,565$ & $44,278,938$ & $47,960,702$ & $49,726,497$ & $23,380,383$ \\
\hline Victoriaville & Price differential wrt Montréal & $4.4 \%$ & $2.0 \%$ & $1.1 \%$ & $3.7 \%$ & $5.4 \%$ & $5.2 \%$ & $3.4 \%$ & $0.3 \%$ & $1.0 \%$ \\
\hline Victoriaville & Price differential wrt Saint-Hyacinthe & $-1.8 \%$ & $-1.8 \%$ & $-2.1 \%$ & $1.7 \%$ & $2.6 \%$ & $3.2 \%$ & $1.4 \%$ & $-0.2 \%$ & $0.1 \%$ \\
\hline$\overline{\text { Magog }}$ & Volumes $^{1}$ & $23,204,970$ & $21,910,795$ & $22,523,590$ & $23,223,458$ & $24,488,323$ & $24,270,856$ & $24,122,723$ & $24,072,872$ & $12,313,014$ \\
\hline Magog & Price differential wrt Montréal & $1.5 \%$ & $2.2 \%$ & $1.5 \%$ & $2.7 \%$ & $4.7 \%$ & $3.6 \%$ & $3.8 \%$ & $2.1 \%$ & $2.9 \%$ \\
\hline Magog & Price differential wrt Saint-Hyacinthe & $-4.5 \%$ & $-1.5 \%$ & $-1.7 \%$ & $0.7 \%$ & $1.8 \%$ & $1.6 \%$ & $1.7 \%$ & $2.0 \%$ & $1.6 \%$ \\
\hline
\end{tabular}

${ }^{1}$ The Magog volumes for 1998-2005 are estimated from the volume of 2005.IV supposing an evolution similar to Sherbrooke.

* Data for the first half of 2006

wrt Montréal

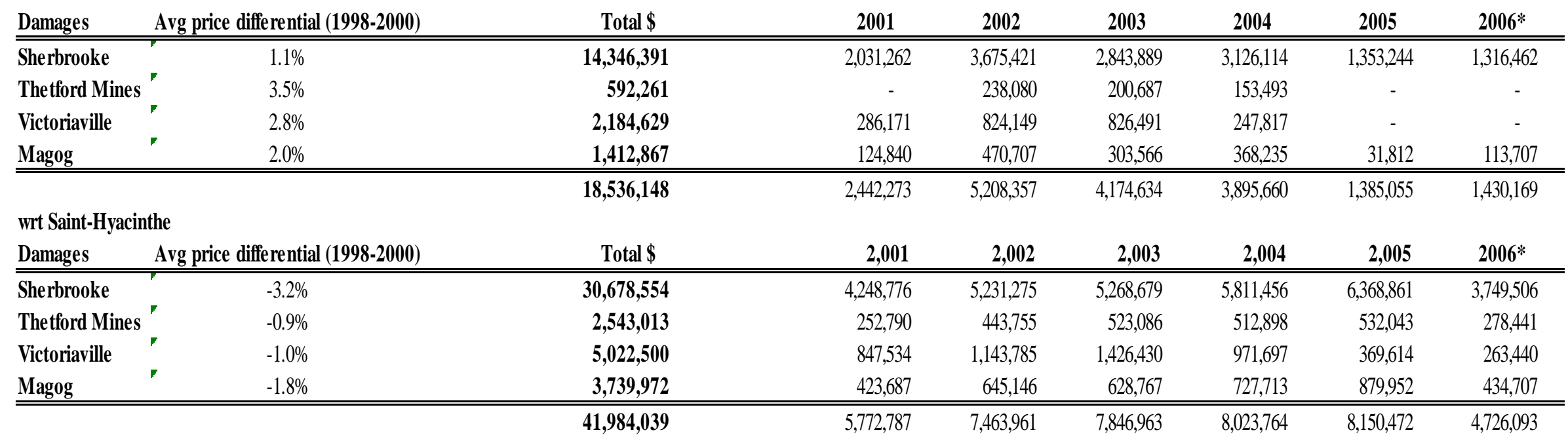


Table 10. Estimate of the economic damages due to overcharges by city and year (2004-2006) with respect to benchmark cities Montréal and Saint-Hyacinthe

\begin{tabular}{|c|c|c|c|c|}
\hline City & Variable & 2004 & 2005 & 2006* \\
\hline Montréal & Price (Régie) & 85.4 & 97.4 & 103.9 \\
\hline Saint-Hyacinthe & Price (Régie) & 86.5 & 97.3 & 104.1 \\
\hline Sherbrooke & Volumes & $135,557,643$ & $135,277,507$ & $68,213,375$ \\
\hline She rbrooke & Price differential wrt Montréal & $3.8 \%$ & $2.2 \%$ & $3.0 \%$ \\
\hline Sherbrooke & Price differential wrt Saint-Hyacinthe & $1.8 \%$ & $1.7 \%$ & $2.1 \%$ \\
\hline Thetford Mines & Volumes & $17,830,695$ & $17,750,979$ & $7,999,771$ \\
\hline Thetford Mines & Price differential wrt Montréal & $4.5 \%$ & $2.7 \%$ & $3.4 \%$ \\
\hline Thetford Mines & Price differential wrt Saint-Hyacinthe & $2.5 \%$ & $2.2 \%$ & $2.5 \%$ \\
\hline Victoriaville & Volumes & $47,960,702$ & $49,726,497$ & $23,380,383$ \\
\hline Victoriaville & Price differential wrt Montréal & $3.4 \%$ & $0.3 \%$ & $1.0 \%$ \\
\hline Victoriaville & Price differential wrt Saint-Hyacinthe & $1.4 \%$ & $-0.2 \%$ & $0.1 \%$ \\
\hline Magog & Volumes & $24,122,723$ & $24,072,872$ & $12,313,014$ \\
\hline Magog & Price differential wrt Montréal & $3.8 \%$ & $2.1 \%$ & $2.9 \%$ \\
\hline Magog & Price differential wrt Saint-Hyacinthe & $1.7 \%$ & $2.0 \%$ & $1.6 \%$ \\
\hline
\end{tabular}

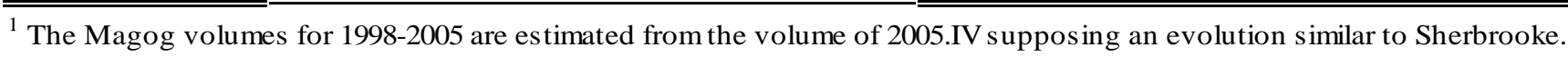

* Data for the first half of 2006

wrt Montréal

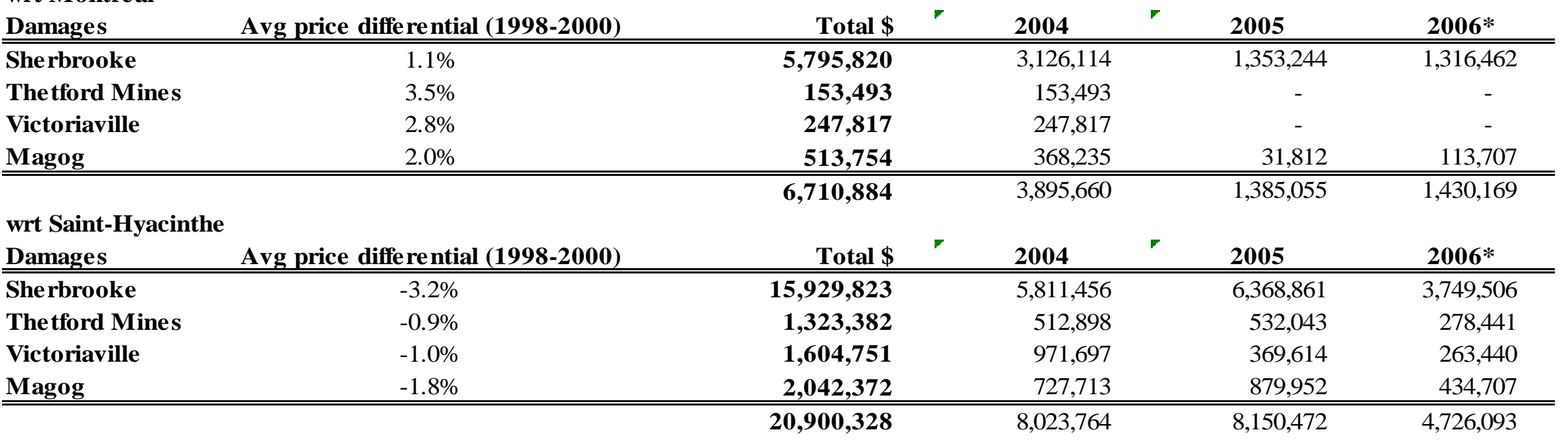

